\title{
Growth and physiological response of rice 'Inpari 35' under salinity stress and application of silicate fertilizer
}

\author{
Aulia Noor Ramadhani ${ }^{1}$, Diah Rachmawati ${ }^{{ }^{*}}$ \\ ${ }^{1}$ Laboratory of Plant Physiology, Faculty of Biology, Universitas Gadjah Mada \\ Jl. Teknika Selatan, Sekip Utara, Sleman, D.I.Yogyakarta, Indonesia. 55281 \\ *Email: drachmawati@ugm.ac.id
}

\begin{abstract}
Rice is an important staple food in Indonesia. Crop areas can be expanded to boost productivity by utilizing marginal lands, which are saline. This study aims to study the growth and physiological response of rice 'Inpari 35 ' to the application of silicate fertilizer under salinity stress conditions. This study used a completely randomized design (CRD) with two factors. The first factor is the difference in $\mathrm{NaCl}$ salt concentration consisting of $\mathrm{N} 0: 0 \mathrm{mM} ; \mathrm{N} 1: 37.5 \mathrm{mM} ; \mathrm{N} 2: 50 \mathrm{mM}$, while the second factor is the difference in the concentration of silicate fertilizer $\left(\mathrm{CaSiO}_{3}\right)$ consisting of S0: $0 \mathrm{mM} ; \mathrm{S} 1: 1 \mathrm{mM}$ and S2: $2 \mathrm{mM}$. Each treatment combination was repeated three times. Observed data were analyzed by analysis of variance (ANOVA). A significant difference between treatments is continued with Duncan's multiple distance test at a $95 \%$ confidence level. The results showed that $\mathrm{NaCl}$ treatment significantly $(\mathrm{p}<0.05)$ inhibited the growth of rice 'Inpari 35', which was indicated by a decrease in the plant height and number of leaves. The $\mathrm{NaCl}$ treatment caused a reduction in the levels of chlorophyll, carotenoids, proline, membrane stability index (MSI), and relative water content (RWC). The interaction between $\mathrm{NaCl}$ treatment and $\mathrm{CaSiO}_{3}$ showed significant differences in physiological parameters by increasing the levels of chlorophyll, carotenoid, proline, membrane stability index, and relative water content.
\end{abstract}

Keywords: hydroponic system; membrane stability index; $\mathrm{NaCl}$ and $\mathrm{CaSiO}_{3}$ treatment; relative water content; rice cultivar

Article History: Received 22 April 2021; Received in revised form 18 June 2021; Accepted 16 November 2021; Available online 30 December 2021

How to Cite This Article: Ramadhani AN, Rachmawati D. 2021. Growth and physiological response of rice 'Inpari 35' under salinity stress and application of silicate fertilizer. Biogenesis: Jurnal Ilmiah Biologi. vol 9(2): 126-136. doi: https://doi.org/10.24252/bio.v9i2.20754.

\section{INTRODUCTION}

Rice is a food crop commodity that produces rice, the staple food in Indonesia. However, the change in land use causes rice production to decline (Jiang et al., 2013; Suhartini \& Harjosudarmo, 2017). One way to increase rice production is by expanding the planted area on marginal lands (Swinton et al., 2011; Hussain et al., 2019), one of which is saline land. In the future, the area of saline land will increase due to the decrease in water quality and rainfall. Salinity-tolerant rice cultivars are needed to take advantage of these marginal lands.

The major current challenge in Indonesia is the conversion of paddy fields to nonagriculture, especially for road infrastructure, airports, offices, housing, and industry (Mahbubi, 2013; Sunartomo, 2015; Mulyani et al., 2017; Septanti \& Saptana, 2019). The lack of updated assessments of the extent, magnitude, and progress of soil salinity and sodicity at different scales is the primary knowledge gap to address the problem of soil salinity (Zhou et al., 2013; Machado \& Serralheiro, 2017; Hassani et al., 2020). Salinity is one of the factors that constrain rice plant growth and production due to the high concentration of sodium chloride $(\mathrm{NaCl})$ in the growing medium, which can interfere with plant physiological processes, affecting osmotic pressure and nutrient balance (Ghosh et al., 2011; Das et al., 2015; Reddy et al., 2017). Thus, other elements are needed that can absorb toxic ions due to salinity stress $(\operatorname{Rad}$ et $a l ., 2012)$. Dry leaf tips, diminished tillers, root length, plant height, shoot dry weight, and root weight are all symptoms of salinity in plants. Salinity decreases the area and concentration of chlorophyll on leaves and reduces lipid peroxidase in cell wall membranes (Weisany et al., 2012; Shah et al., 2017). High salinity levels can induce chloroplast damage which causes a reduction in chlorophyll content and photosynthetic capacity ( $\operatorname{Rad}$ et al., 2012; Gao et al., 2015). 
Silicon $(\mathrm{Si})$ is a well-known crucial element for rice plants, since it provides physical and mechanical protection and also modulates metabolic and physiological functions (Sahebi et al., 2015; Savvas \& Ntatsi, 2015; Luyckx et al., 2017). Silicon contributes to increased plant tolerance to abiotic stress by altering water content levels, lowering water loss through transpiration, regulating nutritional sufficiency, and limiting the absorption of toxic ions such as $\mathrm{Na}^{+}$(Kafi \& Rahimi, 2011; Rizwan et al., 2015; Suhartini \& Harjosudarmo, 2017; Chen et al., 2018). The accumulation of silicic acid $\left(\mathrm{Si}(\mathrm{OH})_{4}\right)$ in the cell walls of leaves, stems, and roots supports plants by assisting in the reduction of ionic poisoning via increased antioxidant enzyme activity under stress situations (Wani et al., 2017; Ikhsanti et al., 2018; Bhat et al., 2019).

Rice plants that are subjected to salinity stress will produce proline and increased membrane permeability as an effort to adjust osmotic pressure (Teh et al., 2015; Chun et al., 2018). In line with Dolatabadian et al. (2011), Zhang et al. (2012), and Aini et al. (2014), salinity can affect the chlorophyll index of the leaf, shorten the root length and diameter, and anatomically disrupt cell division and the process of cell growth by decreasing the thickness of the apical meristem, cortex, and stele diameter. In addition, salinity also stimulates root exodermis and endodermis suberization (Fleck et al., 2011; Cheng et al., 2020).

By conducting this research, information about the role of silicate fertilizer on growth, yield, and tolerance levels of rice 'Inpari 35' to salinity stress can be obtained. Characters that indicate plant adaptive traits to salinity will be observed in growth and physiological changes. As a result, it is important to conduct this research to determine the tolerance of rice 'Inpari 35' under salinity stress conditions and the effect of silicate fertilizer application.

\section{MATERIALS AND METHODS}

This research was conducted at the Laboratory of Plant Physiology and the Laboratory of Plant Structure and Development, Faculty of Biology, Universitas
Gadjah Mada. The research was conducted from December 2020 to March 2021. 'Inpari

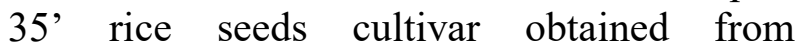
Indonesian Center for Rice Research (ICRC). The design used was a completely randomized design (CRD) with two factors. The first factor is the difference in $\mathrm{NaCl}$ concentration consisting of N0: $0 \mathrm{mM}$; N1: $37.5 \mathrm{mM}$; N2: 50 $\mathrm{mM}$, while the second factor is the difference in $\mathrm{CaSiO}_{3}$ concentration consisting of S0: $0 \mathrm{mM}$; $\mathrm{S} 1: 1 \mathrm{mM}$; and S2: $2 \mathrm{mM}$.

Seed germination. Sterilized rice seeds are sown in a container filled with distilled water and grown at room temperature. Germination was carried out \pm four days until the radicles appeared, then the seeds were transferred to the rockwool growing medium. Uniform germinating seeds were transferred to hydroponic styrofoam measuring $25 \times 20 \times 3$ $\mathrm{cm}$ consisting of six holes of $2.5 \mathrm{~cm}$ in diameter with a distance of $2 \mathrm{~cm}$ and have been coated with plastic gauze on the bottom and installed in a plastic container containing $4 \mathrm{~L}$ of full concentration of Yoshida nutrient solution (Yoshida et al., 1976). Each hole was used to grow one seedling. Hydroponic Yoshida's solution in a plastic container was replaced once a week. Four days old seedlings were acclimatized hydroponically in Yoshida's solution full concentration until 14 DAP (days after planting). The salinity treatments used were $37.5 \mathrm{mM}$ and $50 \mathrm{mM} \mathrm{NaCl}$, while $\mathrm{CaSiO}_{3}$ were 0,1 , and $2 \mathrm{mM}$. The salinity and calcium silicate treatment was carried out during the vegetative period from the age of 14 DAP to 35 DAP.

Plant growth. Plant height and number of leaves were measured every 3 days. Plant height was measured from the root base above the rockwool surface to the tip of the longest leaf. The number of leaves was determined by counting the number of whole leaves in each plant. The measurement of plant dry weight was carried out by drying the plants in an oven at $80^{\circ} \mathrm{C}$ until a constant weight was obtained. Plant dry weight measurements were conducted at the end of the research (21 days after treatment/DAT).

Plant photosynthesis pigments. Chlorophyll and carotenoid according to the 
Harborne (1998) method with some modifications at 14 DAT A leaf sample of $0.3 \mathrm{~g}$ was ground with a mortar and homogenized with $2 \mathrm{ml}$ of $80 \%$ cold acetone solution. Chlorophyll content was determined using a spectrophotometer (Genesys 10 UV Scanning, Thermo Scientific) at multiwavelength of 470 , 645, and $664 \mathrm{~nm}$. The chlorophyll and carotenoid level were calculated by the following formula:

Chlorophyll a level $\left(\mathrm{mg} . \mathrm{L}^{-1}\right)=12.21 \times \mathrm{A}_{(663)}-2.81 \times$ A(646)

Chlorophyll b level $\left(\mathrm{mg} . \mathrm{L}^{-1}\right)=20.13 \times \mathrm{A}_{(646)}-5.03 \times$ A(663)

Then, converted into $\mathrm{mg} \cdot \mathrm{g}^{-1}$, by the following formula (Harborne, 1998):

Chlorophyll level (mg. $\mathrm{g}^{-1}$ )

$=\frac{1.100^{-1} \mathrm{x} \text { chlorophyll level }}{0.1 \mathrm{mg} \cdot \mathrm{g}^{-1}}$

Carotenoid level (mg. $\left.\mathrm{g}^{-1}\right)$

$=\frac{(1000 \mathrm{~A} 6470)-3.27(\mathrm{ChA})-104(\mathrm{Ch} \mathrm{B})]}{227}$

Membrane stability index. Measurement of the membrane stability index (Swapna \& Shylaraj, 2017) was carried out on the $14^{\text {th }}$ day after treatment. Leaf samples were taken from three plants from each replication as much as $0.1 \mathrm{~g}$. The leaves were put into a clean test tube containing $10 \mathrm{ml}$ of $\mathrm{ddH}_{2} \mathrm{O}$, then incubated for $\pm 24 \mathrm{~h}$ at room temperature under constant lighting. The initial conductivity value (EC1) is measured using an EC meter. After that, the tube was heated in boiling air $\left(100^{\circ} \mathrm{C}\right)$ for 30 min and then cooled to $25^{\circ} \mathrm{C}$ for $15 \mathrm{~min}$. The conductivity of the solution was measured with an EC meter as the final conductivity value (EC2). The membrane stability index (MSI) value is calculated by the following formula (Swapna \& Shylaraj, 2017):

$\mathrm{MSI}=\left(1-\frac{E C 1}{E C 2}\right) \times 100$

\section{Relative Water Content (RWC).} Measurement of RWC was carried out after the $14^{\text {th }}$ day of treatment (Polash et al., 2018). Leaf samples were taken from three plants from each replication as much as $0.1 \mathrm{~g}$. Leaf samples were

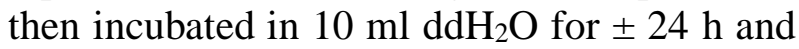
then the turgid weight was weighed. The leaf samples were then put in a brown paper bag and dried in an oven at a temperature of $70^{\circ} \mathrm{C}$ for \pm $72 \mathrm{~h}$, then the dry weight of the sample was weighed. The value of RWC is calculated using the following formula (González \& GonzálezVilar, 2001):

RWC $=\frac{\text { Fresh weight }- \text { dry weight }}{\text { Turgid weight }- \text { dry weight }} \times 100$

Proline content measurement. Proline contents were measured according to the Bates et al. (1973) method at 19 DAT. A total of 0.25 $\mathrm{g}$ fresh leaves were frozen using liquid nitrogen and mashed with a mortar. The sample were extracted with sulfosalicylic acid $3 \%$ and mixed with ninhydrin reagents and heated in $95^{\circ} \mathrm{C}$ water bath for $60 \mathrm{~min}$. About $2 \mathrm{ml}$ of toluene were added after the sample has cooled to form two layers of solution. The absorbance of the extract was determined by spectrophotometry with toluene as blank. Proline levels were calculated as $\mu g \cdot \mathrm{ml}^{-1}$ using calibration with a proline standard curve. The level of proline $\mu$ mol per gram of fresh sample weight was calculated using the following formula (Bates et al., 1973):

Proline level

$=\frac{[\mu \mathrm{g} \text { proline } / . \mathrm{mlx} \mathrm{ml} \text { toluent }] /[115,13 \mu \mathrm{g} / \mu \mathrm{mol}]}{0,25}$

Data analysis. Following our previous studies (Rachmawati et al., 2021), the significance and interaction values of $\mathrm{NaCl}$ and $\mathrm{CaSiO}_{3}$ treatment on plant growth and plant physiological parameters were tested with OneWay ANOVA and continued with Duncan Multiple Range Test (DMRT) conducted at $95 \%$ confidence level $(\mathrm{p} \leq 0.05)$ with IBM-SPSS ver. 26.0 .

\section{RESULTS AND DISCUSSION}

The present study examined the growth and physiological responses of rice 'Inpari 35' when treated with $\mathrm{CaSiO}_{3}$ as a source of silicon (Si) at varied concentrations and exposed to 
salinity stress. Silicon is an inorganic fertilizer needed in rice cultivation since it contributes to the quality and quantity of agricultural products
(Meena et al., 2014). Fig.1 showed the morphology of rice 'Inpari 35' with a combination of $\mathrm{NaCl}$ and $\mathrm{CaSiO}_{3}$ treatments.

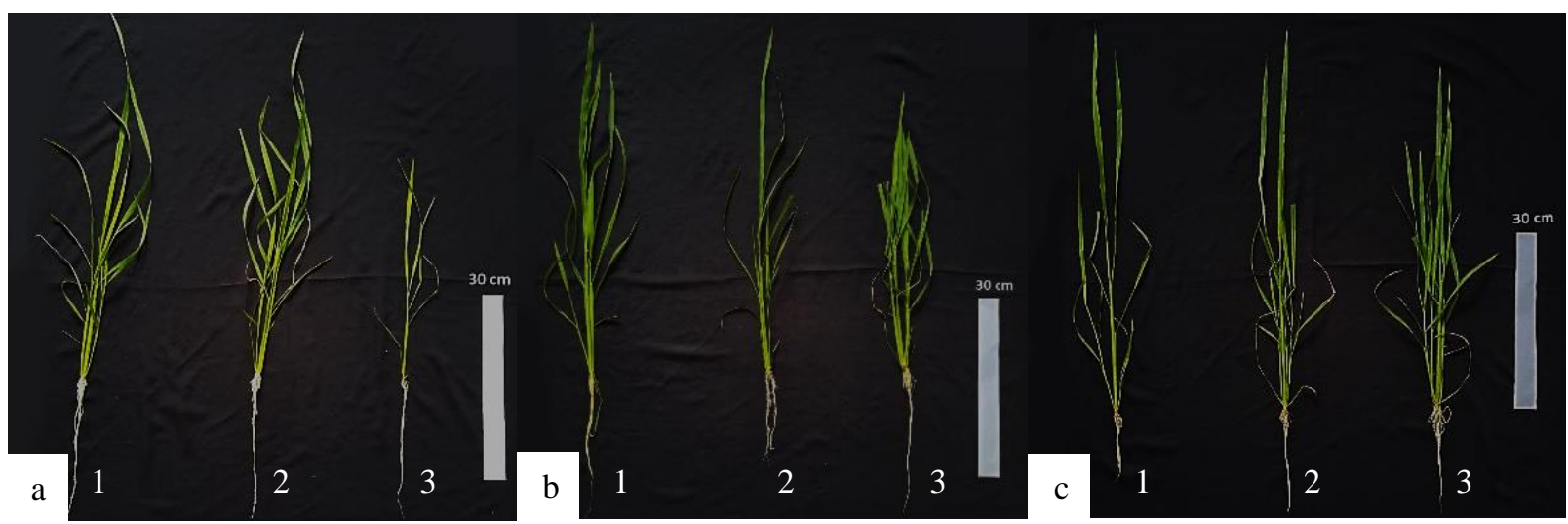

Fig 1. Morphology of rice 'Inpari 35' with $\mathrm{NaCl}_{\text {and }} \mathrm{CaSiO}_{3}$ treatment: a. 0 mM CaSiO3; b. 1 mM CaSiO $3\left(\mathrm{~S}_{3}\right)$; c. $\mathrm{CaSiO}_{3}$ $2 \mathrm{mM}(\mathrm{S} 2) ; 1.0 \mathrm{mM} \mathrm{NaCl}(\mathrm{N} 0) ; 2.37 .5 \mathrm{mM} \mathrm{NaCl}(\mathrm{N} 1) ; 3.50 \mathrm{mM} \mathrm{NaCl}(\mathrm{N} 2) ;$ bars= $30 \mathrm{~cm}$.

Plant height. Plant height parameters were measured every three days up to 21 days of treatment which is shown in Fig. 2-4. Based on the observations, treatment $1 \mathrm{mM}$ and $2 \mathrm{mM}$ $\mathrm{CaSiO}_{3}$ increased plant height compared to control (Fig. 3).

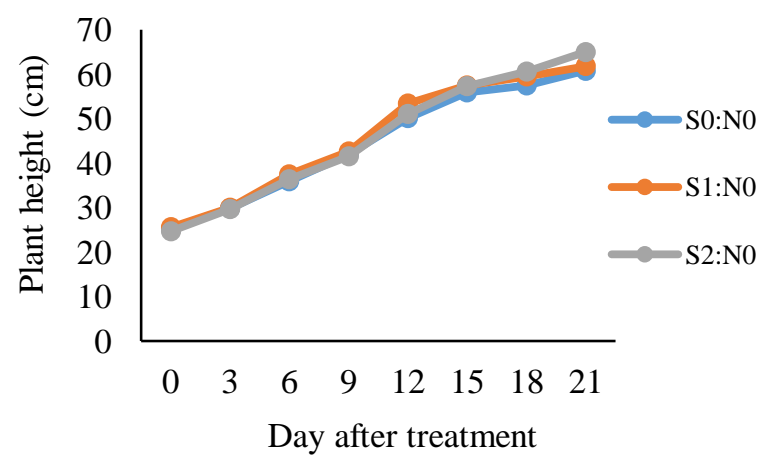

Fig 2. Plant height of rice 'Inpari 35' treated with $\mathrm{NaCl}$ and $\mathrm{CaSiO}_{3}$ using $0 \mathrm{mM} \mathrm{NaCl}$ (N0) (S0: $0 \mathrm{mM} \mathrm{CaSiO}$; $\mathrm{S} 1: 1 \mathrm{mM} \mathrm{CaSiO}_{3}$; $\mathrm{S} 2: 2 \mathrm{mM} \mathrm{CaSiO}_{3}$ for three weeks).

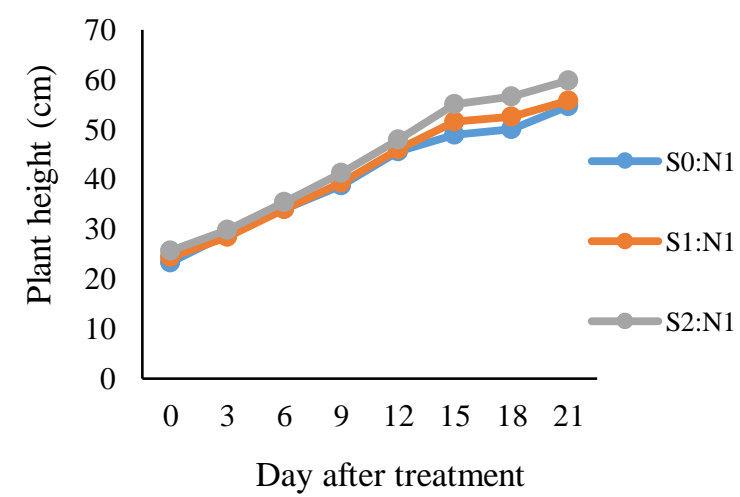

Fig 3. Plant height of rice 'Inpari 35' treated with $\mathrm{NaCl}$ and $\mathrm{CaSiO}_{3}$ using $37.5 \mathrm{mM} \mathrm{NaCl}$ (N1) (SO: $0 \mathrm{mM}$ $\mathrm{CaSiO}_{3} ; \mathrm{S} 1: 1 \mathrm{mM} \mathrm{CaSiO}_{3} ; \mathrm{S} 2: 2 \mathrm{mM} \mathrm{CaSiO}_{3}$ for three weeks).

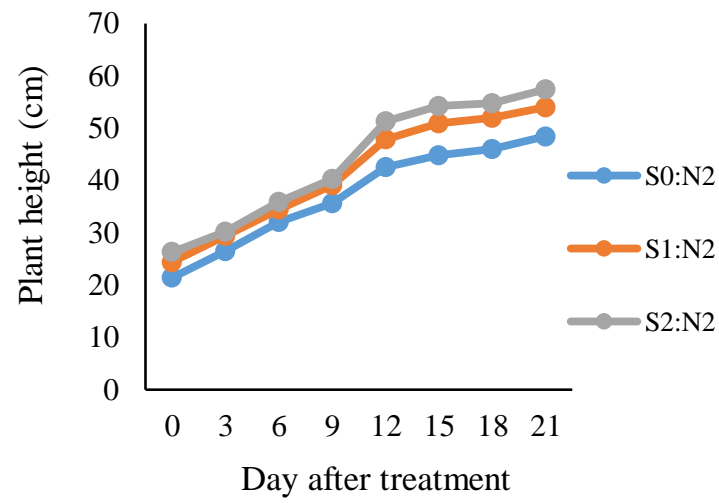

Fig 4. Plant height of rice 'Inpari 35' treated with $\mathrm{NaCl}$ and $\mathrm{CaSiO}_{3}$ using $50 \mathrm{mM} \mathrm{NaCl}(\mathrm{N} 2)$ (So: $0 \mathrm{mM} \mathrm{CaSiO}_{3}$; $\mathrm{S} 1: 1 \mathrm{mM} \mathrm{CaSiO}_{3}$; $\mathrm{S} 2: 2 \mathrm{mM} \mathrm{CaSiO}_{3}$ for three weeks).

The treatment without $\mathrm{NaCl}$ by application of $\mathrm{CaSiO}_{3} 1 \mathrm{mM}$ and $2 \mathrm{mM}$ increased plant height compared to control (Fig. 2). In Fig. 3, $\mathrm{NaCl}$ treatment at $37.5 \mathrm{mM}$ with $\mathrm{CaSiO}_{3} 2 \mathrm{mM}$ showed a higher plant height than $37.5 \mathrm{mM}$ $\mathrm{NaCl}$ treatment with $\mathrm{CaSiO}_{3} 1 \mathrm{mM}$ or without Si. Fig. 4 showed $\mathrm{NaCl}$ treatment at $50 \mathrm{mM}$ with $\mathrm{CaSiO}_{3} 2 \mathrm{mM}$ showed a higher plant height increase than $50 \mathrm{mM} \mathrm{NaCl}$ treatment with $\mathrm{CaSiO}_{3}$ or without $\mathrm{CaSiO}_{3} 1 \mathrm{mM}$. The higher $\mathrm{CaSiO}_{3}$ concentration given, the higher the plant height increase. High concentrations of $\mathrm{Na}^{+}$and $\mathrm{Cl}^{-}$cause toxicity to plants and thus inhibit growth. Salinity reduces plant growth through osmotic stress, reduces the ability of plants to absorb water, and causes inhibition of plant growth (Rad et al., 2012). 
Table 1. Plant height of rice 'Inpari 35' after treated with $\mathrm{CaSiO}_{3}$ and $\mathrm{NaCl}$ for three weeks.

\begin{tabular}{lllll}
\hline $\begin{array}{l}\mathrm{NaCl} \\
(\mathrm{mM})\end{array}$ & 0 & $\mathrm{CaSiO}_{3}(\mathrm{mM})$ & 2 & Average \\
\hline 0 & $60.82 \mathrm{ef}$ & $61.78 \mathrm{ef}$ & $65.03 \mathrm{f}$ & $62.54 \mathrm{r}$ \\
37.5 & $54.79 \mathrm{~b}$ & $55.81 \mathrm{bc}$ & $59.87 \mathrm{de}$ & $56.82 \mathrm{q}$ \\
50 & $48.45 \mathrm{a}$ & $54.02 \mathrm{~b}$ & $57.42 \mathrm{bcd}$ & $53.29 \mathrm{p}$ \\
Average & $54.69 \mathrm{x}$ & $57.20 \mathrm{y}$ & $60.77 \mathrm{z}$ & \\
\hline
\end{tabular}

Note: Numbers followed by the same letters in columns and rows show insignificant differences based on the DMRT test with a confidence level of $95 \%$.

ANOVA analysis revealed that differences in $\mathrm{NaCl}$ and $\mathrm{CaSiO}_{3}$ treatments had a significant influence on the plant height of rice 'Inpari35' (p0.05). According to Table 1, NaCl treatment without $\mathrm{CaSiO}_{3}$ resulted in a reduction in rice plant height compared to control. This shows that $\mathrm{NaCl}$ treatment with a concentration of $37.5 \mathrm{mM}$ and $50 \mathrm{mM}$ inhibit the growth of rice plant height.

Number of leaves. The parameter number of leaves were measured every three days up to 21 days of treatment, which is shown in Fig. 57.

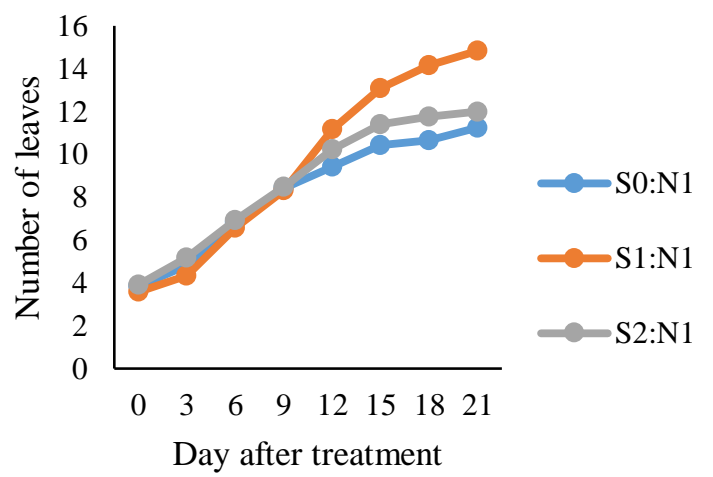

Fig 5. Number of leaves of rice 'Inpari 35' rice plant treated with $\mathrm{NaCl}$ and $\mathrm{CaSiO}_{3}$ using $0 \mathrm{mM} \mathrm{NaCl}$ (N0) (S1: $1 \mathrm{mM} \mathrm{CaSiO}_{3} ; \mathrm{S} 2: 2 \mathrm{mM} \mathrm{CaSiO}_{3}$ for three weeks).

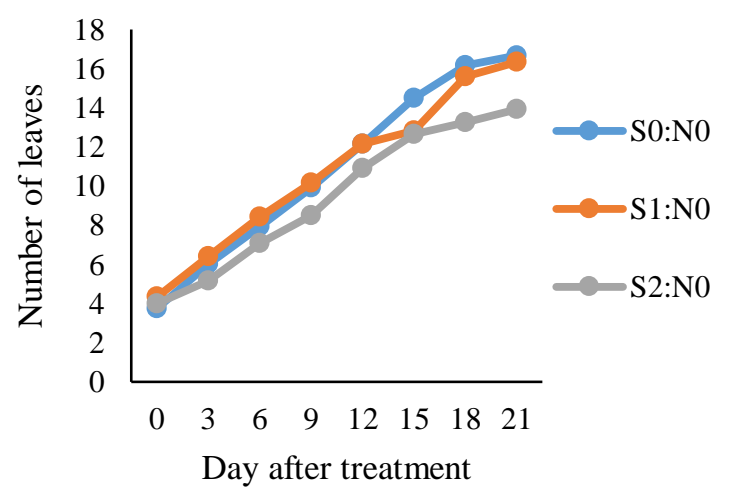

Fig 6. Number of leaves of rice 'Inpari 35 ' rice plant treated with $\mathrm{NaCl}$ and $\mathrm{CaSiO}_{3}$ using $37.5 \mathrm{mM} \mathrm{NaCl}$ (N1) (S1: $1 \mathrm{mM} \mathrm{CaSiO}_{3} ; \mathrm{S} 2: 2 \mathrm{mM} \mathrm{CaSiO}_{3}$ for three weeks).

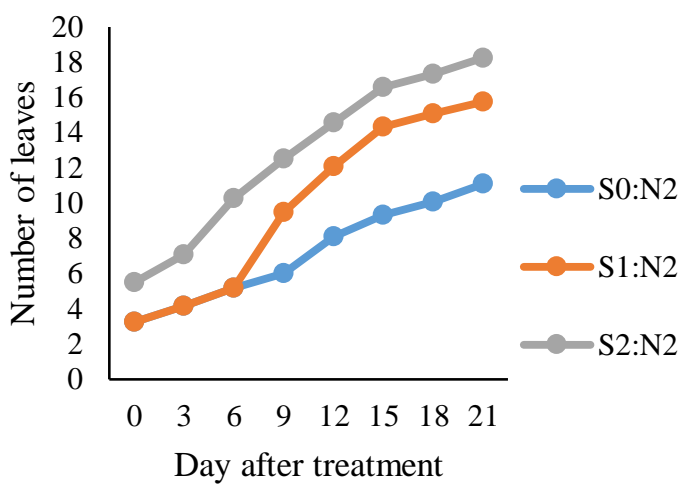

Fig 7. Number of leaves of rice 'Inpari 35' rice plant treated with $\mathrm{NaCl}$ and $\mathrm{CaSiO}_{3}$ using $50 \mathrm{mM} \mathrm{NaCl}$ (N2) (S1: $1 \mathrm{mM} \mathrm{CaSiO}_{3} ; \mathrm{S} 2: 2 \mathrm{mM} \mathrm{CaSiO}_{3}$ for three weeks).

The control treatment without $\mathrm{NaCl}$ showed that the number of leaves was more increased in the treatment with $1 \mathrm{mM}$ and $2 \mathrm{mM}$ $\mathrm{CaSiO}_{3}$ (Fig. 5). The treatment of $37.5 \mathrm{mM}$ $\mathrm{NaCl}$ with $1 \mathrm{mM} \mathrm{CaSiO}{ }_{3}$ showed a higher number of leaves than that with $2 \mathrm{mM} \mathrm{CaSiO}_{3}$ (Fig. 6). The treatment of $50 \mathrm{mM} \mathrm{NaCl}$ with 2 $\mathrm{mM} \mathrm{CaSiO} 3$ showed a higher number of leaves than without $\mathrm{CaSiO}_{3}$ or with $1 \mathrm{mM} \mathrm{CaSiO}$ (Fig. 7). $\mathrm{CaSiO}_{3}$ concentration boosted silicon intake, resulting in an increase in the number of leaves on rice plants. Leaf damage due to $\mathrm{NaCl}$ treatment on rice seedling occurs as a result of the excessive transport of $\mathrm{Na}^{+}$and $\mathrm{Cl}^{-}$ions which cause $\mathrm{Na}^{+}$and $\mathrm{Cl}^{-}$to accumulate in the leaves tissues (Khare et al., 2015; Almeida et al., 2017). As a result of this excessive ion transport, leakage occurs through the apoplastic pathway to the xylem (Zhao et al., 2020).

Table 2. Number of leaves of rice 'Inpari 35' after treated with $\mathrm{CaSiO}_{3}$ and $\mathrm{NaCl}$ for three weeks.

\begin{tabular}{lllll}
\hline $\begin{array}{l}\mathrm{NaCl} \\
(\mathrm{mM})\end{array}$ & 0 & $\mathrm{CaSiO}_{3}(\mathrm{mM})$ & 2 & Average \\
\hline 0 & $16.67 \mathrm{~cd}$ & $16.33 \mathrm{~cd}$ & $13.92 \mathrm{abc}$ & $15.64 \mathrm{q}$ \\
37.5 & $11.25 \mathrm{a}$ & $14.83 \mathrm{bc}$ & $12.00 \mathrm{ab}$ & $12.69 \mathrm{p}$ \\
50 & $11.08 \mathrm{a}$ & $15.75 \mathrm{~cd}$ & $18.25 \mathrm{~d}$ & $15.03 \mathrm{q}$ \\
Average & $13.00 \mathrm{x}$ & $14.72 \mathrm{y}$ & $15.64 \mathrm{y}$ & \\
\hline
\end{tabular}

According to Table 2, treatment with 37.5 $\mathrm{mM}$ and $50 \mathrm{mM} \mathrm{NaCl}$ without $\mathrm{CaSiO}_{3}$ resulted in a reduction in the number of leaves compared to the control. The results of the ANOVA test, the number of leaves decreased significantly $(\mathrm{p}<0.05)$ with $\mathrm{NaCl}$ treatment without $\mathrm{CaSiO}_{3}$ 
treatment. However, the $50 \mathrm{mM} \mathrm{NaCl}$ and 2 $\mathrm{mM} \mathrm{CaSiO}_{3}$ treatments showed a significantly different number of leaves compared to the 50 $\mathrm{mM} \mathrm{NaCl}$ treatment without $\mathrm{CaSiO}_{3}$. Application of $1 \mathrm{mM}$ and $2 \mathrm{mM} \mathrm{CaSiO}_{3}$ on rice 'Inpari 35' at a $50 \mathrm{mM} \mathrm{NaCl}$ treatment concentration showed that the number of leaves tended to increase compared to the $\mathrm{NaCl}$ treatment without $\mathrm{CaSiO}_{3}$ application. Salinity treatment with $\mathrm{NaCl}$ inhibits the growth process of rice plants.

Dry weight. Plant dry weight represent the yield of growth. The increase in dry weight indicates that the plant is growing and developing more rapidly. Root and shoot dry weight of rice 'Inpari 35' at five weeks of age are presented in Tables 3.

Tabel 3. Root and shoot dry weight of rice 'Inpari 35' after treated with $\mathrm{CaSiO}_{3}$ and $\mathrm{NaCl}$ for three weeks.

\begin{tabular}{|c|c|c|c|c|c|}
\hline Parameter & $\mathrm{NaCl}(\mathrm{mM})$ & \multicolumn{3}{|c|}{$\mathrm{CaSiO}_{3}(\mathrm{mM})$} & Average \\
\hline Root dry & 0 & $0.142 \mathrm{~g}$ & $0.080 \mathrm{~d}$ & $0.040 \mathrm{~b}$ & $0.087 \mathrm{p}$ \\
\hline weight & 37.5 & $0.085 \mathrm{~d}$ & $0.081 \mathrm{~d}$ & $0.071 \mathrm{c}$ & $0.079 q$ \\
\hline (gram) & 50 & $0.028 \mathrm{a}$ & $0.117 \mathrm{e}$ & $0.129 f$ & $0.091 \mathrm{p}$ \\
\hline & Average & $0.085 y$ & $0.093 \mathrm{z}$ & $0.080 \mathrm{x}$ & \\
\hline Shoot dry & 0 & $0.671 d$ & $0.615 \mathrm{~cd}$ & $0.406 b$ & $0.564 q$ \\
\hline weight & 37.5 & $0.451 b$ & $0.553 \mathrm{c}$ & $0.614 \mathrm{~cd}$ & $0.539 q$ \\
\hline (gram) & 50 & $0.131 \mathrm{a}$ & $0.636 \mathrm{~cd}$ & $0.660 \mathrm{~cd}$ & $0.476 \mathrm{p}$ \\
\hline & Average & $0.418 x$ & $0.599 y$ & $0.560 y$ & \\
\hline
\end{tabular}

Note: Numbers followed by the same letters in columns and rows show insignificant differences based on the DMRT test with a confidence level of $95 \%$.

Table 3 showed that the $0 \mathrm{mM}$ and 37.5 $\mathrm{mM} \mathrm{NaCl}$ treatment decreased root dry weight and increased $\mathrm{CaSiO}_{3}$ application. However, at $50 \mathrm{mM} \mathrm{NaCl}$ treatment, the root dry weight increased along with the increasing $\mathrm{CaSiO}_{3}$ application. The greater the dry weight indicated, the better the metabolism occurs in the plant cells, and vice versa (Jayantie et al., 2017). The measurement of rice shoot dry weight showed that $0 \mathrm{mM} \mathrm{NaCl}$ treatment and increasing $\mathrm{CaSiO}_{3}$ application tended to decrease the shoot dry weight. However, at 37.5 $\mathrm{mM}$ and $50 \mathrm{mM} \mathrm{NaCl}$ treatment, increasing $\mathrm{CaSiO}_{3}$ concentration increases the shoot dry weight (Table 3 ). The calcium can prevent the rate of leaves dropping to prevent plant weight loss (Gilliham et al., 2011). Plant under $\mathrm{NaCl}$ treatment with the application of $\mathrm{CaSiO}_{3}$ has a larger leaf weight ratio than plants without $\mathrm{CaSiO}_{3}$ application, indicated with loss of water transpiration. $\mathrm{CaSiO}_{3}$ in nutrient solutions increased rice shoot dry weight (Sahebi et al., 2015).

Plant photosynthesis pigments. Chlorophyll functions in the photosynthetic process of plants by collecting and converting sunlight into chemical energy. Chlorophyll parameter measurements offer information about the activity of photosystem II (PSII) and changes in the photosynthetic metabolism of plants under abiotic stress (Chen et al., 2011).

Table 4. Chlorophyll a and chlorophyll b levels of rice 'Inpari 35' rice plants after treated with $\mathrm{CaSiO}_{3}$ and $\mathrm{NaCl}$ for three weeks.

\begin{tabular}{llllll}
\hline \multirow{2}{*}{ Parameter } & \multirow{2}{*}{$\mathrm{NaCl}(\mathrm{mM})$} & \multicolumn{2}{l}{$\mathrm{CaSiO}_{3}(\mathrm{mM})$} & \multicolumn{2}{c}{ Average } \\
\hline \multirow{2}{*}{ Chlorophyll a mg.g ${ }^{-1}$} & 0 & 0 & 1 & 2 & $2.137 \mathrm{q}$ \\
Fresh weight & 37.5 & $0.698 \mathrm{a}$ & $0.806 \mathrm{a}$ & $1.224 \mathrm{a}$ & $0.909 \mathrm{p}$ \\
& 50 & $0.654 \mathrm{a}$ & $1.108 \mathrm{a}$ & $1.532 \mathrm{a}$ & $1.098 \mathrm{p}$ \\
& Average & $0.790 \mathrm{x}$ & $0.928 \mathrm{x}$ & $2.426 \mathrm{y}$ & \\
Chlorophyll b mg.g ${ }^{-1}$ & 0 & $1.522 \mathrm{a}$ & $1.874 \mathrm{a}$ & $3.347 \mathrm{~b}$ & $1.498 \mathrm{p}$ \\
Fresh weight & 37.5 & $1.685 \mathrm{a}$ & $1.825 \mathrm{a}$ & $1.742 \mathrm{a}$ & $1.209 \mathrm{p}$ \\
& 50 & $1.472 \mathrm{a}$ & $2.434 \mathrm{ab}$ & $3.234 \mathrm{~b}$ & $1.587 \mathrm{p}$ \\
\hline
\end{tabular}

Note: Numbers followed by the same letters in columns and rows show insignificant differences based on the DMRT test with a confidence level of $95 \%$. 
Based on Table 4, $\mathrm{NaCl}$ treatment showed no significant difference $(p \geq 0.05)$ to chlorophyll $b$ levels. However, increasing the $\mathrm{NaCl}$ concentration can decrease chlorophyll a levels. Application of $2 \mathrm{mM} \mathrm{CaSiO} 3$ to plant with $50 \mathrm{mM} \mathrm{NaCl}$ treatment increased chlorophyll a levels significantly $(p<0.05)$. However, the application of $\mathrm{CaSiO}_{3}$ to plant with $37.5 \mathrm{mM} \mathrm{NaCl}$ treatment did not significantly increase chlorophyll a levels $(p \geq 0.05)$. The highest chlorophyll a levels were found in plants treated without $\mathrm{NaCl}$ and given $2 \mathrm{mM}$ of $\mathrm{CaSiO}_{3}$. Saline conditions cause changes in chlorophyll levels resulting from the damage to the chloroplasts, which is indicated by the chlorophyll a level that is lower than the chlorophyll b level. Degradation of chlorophyll $a$ in the seedling stage treated with $\mathrm{NaCl}$ was associated with photosystem II which caused a decrease in photosynthesis rate (Amirjani, 2011). Table 4 shows that chlorophyll levels decreased at $50 \mathrm{mM} \mathrm{NaCl}$ treatment. Application of $1 \mathrm{mM}$ and $2 \mathrm{mM} \mathrm{CaSiO}_{3}$ to plants treated with $\mathrm{NaCl}$ or without $\mathrm{NaCl}$ could increase chlorophyll $\mathrm{b}$ levels. About $2 \mathrm{mM}$ $\mathrm{CaSiO}_{3}$ increased chlorophyll b levels significantly $(\mathrm{p} \geq 0.05)$. The highest chlorophyll $\mathrm{b}$ was found in plants treated without $\mathrm{NaCl}$ with $2 \mathrm{mM} \mathrm{CaSiO}_{3}$.

Our study showed that application of $\mathrm{CaSiO}_{3}$ tends to increase the levels of chlorophyll $\mathrm{a}$ and chlorophyll $\mathrm{b}$ of rice plant under salinity stress (Table 4). Decrease in chlorophyll levels at high $\mathrm{NaCI}$ concentration (50 $\mathrm{mM}$ ) can be caused by damage to chloroplasts or changes in the ratio of lipid protein complexes to pigment proteins, as well as an increase in chlorophyllase activity (Taïbi et al., 2016). In addition, NaCI treatment caused several structural changes in the leaves.

Table 5. Carotenoid levels of rice 'Inpari 35' after treated with $\mathrm{CaSiO}_{3}$ and $\mathrm{NaCl}$ for three weeks.

\begin{tabular}{lllll}
\hline $\mathrm{NaCl}$ & \multicolumn{2}{l}{$\mathrm{CaSiO}_{3}(\mathrm{mM})$} & & \multirow{2}{*}{ Average } \\
$(\mathrm{mM})$ & 0 & 1 & 2 & \\
\hline 0 & $0.118 \mathrm{a}$ & $0.110 \mathrm{a}$ & $0.384 \mathrm{~b}$ & $0.204 \mathrm{q}$ \\
37.5 & $0.089 \mathrm{a}$ & $0.101 \mathrm{a}$ & $0.145 \mathrm{a}$ & $0.112 \mathrm{p}$ \\
50 & $0.084 \mathrm{a}$ & $0.140 \mathrm{a}$ & $0.190 \mathrm{a}$ & $0.138 \mathrm{pq}$ \\
Average & $0.097 \mathrm{x}$ & $0.117 \mathrm{x}$ & $0.239 \mathrm{y}$ & \\
\hline
\end{tabular}

Note: Numbers followed by the same letters in columns and rows show insignificant differences based on the DMRT test with a confidence level of $95 \%$.
The $\mathrm{NaCl}$ treatment did not show a significant difference $(p \geq 0.05)$ to the carotenoid levels, but the $\mathrm{NaCl}$ treatment tended to reduce the carotenoid levels. Application of $2 \mathrm{mM}$ $\mathrm{CaSiO}_{3}$ without $\mathrm{NaCl}$ treatment increased carotenoid levels significantly (Table 5). Overall, the application of $\mathrm{CaSiO}_{3}$ to plants treated with $37.5 \mathrm{mM} \mathrm{NaCl}, 50 \mathrm{mM} \mathrm{NaCl}$, or without $\mathrm{NaCl}$ increased carotenoid levels. The application of $\mathrm{CaSiO}_{3}$ to plants with $\mathrm{NaCl}$ treatment did not increase carotenoid levels significantly $(\mathrm{p} \geq 0.05)$. The highest carotenoid levels were found in plants without $\mathrm{NaCl}$ with the application of $2 \mathrm{mM} \mathrm{CaSiO}$. Carotenoids consist of carotene and xanthophyll which represent the photosynthetic pigment group, play a role in harvesting photon energy for photosynthesis (Maoka, 2020), and as defense mechanisms against oxidative stress. The carotenoid pigments degenerate to maintain chlorophyll levels, which is one of the most important mechanisms in rice plants under salinity stress (Taïbi et al., 2016).

Membrane stability index (MSI). $\mathrm{NaCl}$ treatment increased the electrolyte leakage value and decreased the MSI value, which effects were more visible on plants as the $\mathrm{NaCl}$ concentration increased (Senguttuvel et al., 2013). The results of measuring the MSI parameters in the rice 'Inpari 35' with $\mathrm{CaSiO}_{3}$ and $\mathrm{NaCl}$ treatment are presented in Table 6.

Table 6. Membrane stability index (MSI) of rice 'Inpari 35' after treated with $\mathrm{CaSiO}_{3}$ and $\mathrm{NaCl}$ for three weeks.

\begin{tabular}{lllll}
\hline $\mathrm{NaCl}$ & \multicolumn{2}{l}{$\mathrm{CaSiO}_{3}(\mathrm{mM})$} & & \multirow{2}{*}{ Average } \\
$(\mathrm{mM})$ & 0 & 1 & 2 & \\
\hline 0 & $92.737 \mathrm{~b}$ & $92.493 \mathrm{~b}$ & $93.073 \mathrm{~b}$ & $92.768 \mathrm{q}$ \\
37.5 & $75.047 \mathrm{a}$ & $92.450 \mathrm{~b}$ & $89.687 \mathrm{~b}$ & $85.728 \mathrm{p}$ \\
50 & $75.460 \mathrm{a}$ & $92.14 \mathrm{~b}$ & $92.690 \mathrm{~b}$ & $86.763 \mathrm{p}$ \\
Average & $81.081 \mathrm{x}$ & $92.361 \mathrm{y}$ & $91.817 \mathrm{y}$ & \\
\hline
\end{tabular}

Note: Numbers followed by the same letters in columns and rows show insignificant differences based on the DMRT test with a confidence level of $95 \%$.

The MSI value of rice 'Inpari 35' treated with $50 \mathrm{mM} \mathrm{NaCl}$ increased with increasing $\mathrm{CaSiO}_{3}$ concentration. The application of $1 \mathrm{mM}$ and $2 \mathrm{mM}$ of $\mathrm{CaSiO}_{3}$ with $37.5 \mathrm{mM}$ and $50 \mathrm{mM}$ $\mathrm{NaCl}$ treatment showed a significant difference $(p<0.05)$ compared to the $\mathrm{NaCl}$ treatment without application of $\mathrm{CaSiO}_{3}$. The control plant had the highest membrane stability index value compared to other treatments. Between 
$\mathrm{NaCl}$ treatment and $\mathrm{CaSiO}_{3}$ application, there was a significant difference $(\mathrm{p}<0.05)$. The MSI measurement results in Table 6 show that the MSI value tends to decrease with the increasing concentration of $\mathrm{NaCl}$ treatment. The decrease in the membrane stability index might be due to the accumulation of $\mathrm{Na}^{+}$and $\mathrm{Cl}^{-}$ions. The reduction of $\mathrm{Na}^{+}$uptake and $\mathrm{Na}^{+}$accumulation by plant tissues is the most important plant resistance to salinity stress. It is well established that $\mathrm{Si}$ supply from $\mathrm{CaSiO}_{3}$ reduces $\mathrm{Na}^{+}$ absorption by plants under salt stress and increases the $\mathrm{K}^{+} / \mathrm{Na}^{+}$ratio (Zargar et al., 2019).

Relative water content (RWC) is a salinity tolerance metric in plants that describes the relative water content of the leaves and indicates the plant's stress level. The results of measurement of RWC parameters in rice 'Inpari 35' with $\mathrm{CaSiO} 3$ and $\mathrm{NaCl}$ treatment are presented in Table 7.

Table 7. Relative water content (RWC) of rice 'Inpari 35' after treated with $\mathrm{CaSiO}_{3}$ and $\mathrm{NaCl}$ for three weeks.

\begin{tabular}{lllll}
\hline $\mathrm{NaCl}$ & \multicolumn{2}{l}{$\mathrm{CaSiO}_{3}(\mathrm{mM})$} & & Average \\
$(\mathrm{mM})$ & 0 & 1 & 2 & \\
\hline 0 & $92.440 \mathrm{ab}$ & $92.230 \mathrm{ab}$ & $95.99 \mathrm{~b}$ & $93.553 \mathrm{p}$ \\
37.5 & $82.563 \mathrm{a}$ & $92.360 \mathrm{ab}$ & $92.113 \mathrm{ab}$ & $89.012 \mathrm{p}$ \\
50 & $82.357 \mathrm{a}$ & $92.14 \mathrm{ab}$ & $96.093 \mathrm{~b}$ & $90.197 \mathrm{p}$ \\
Average & $85.787 \mathrm{x}$ & $92.243 \mathrm{y}$ & $94.732 \mathrm{y}$ & \\
\hline
\end{tabular}

Note: Numbers followed by the same letters in columns and rows show insignificant differences based on the DMRT test with a confidence level of $95 \%$.

Table 7 shows that the $\mathrm{NaCl}$ treatment tends to decrease the RWC, but it increased by applying $1 \mathrm{mM}$ or $2 \mathrm{mM} \mathrm{CaSiO}_{3}$. Treatment of $37.5 \mathrm{mM} \mathrm{NaCl}$ by application of $1 \mathrm{mM} \mathrm{CaSiO}_{3}$ increased the RWC compared without $\mathrm{CaSiO}_{3}$. The $37.5 \mathrm{mM} \mathrm{NaCl}$ treatment slightly decreased in the RWC when given $2 \mathrm{mM}$ $\mathrm{CaSiO}_{3}$ but significantly different from 37.5 $\mathrm{mM} \mathrm{NaCl}$ treatment without $\mathrm{CaSiO}_{3}$. The RWC on $50 \mathrm{mM} \mathrm{NaCl}$ treatment tended to increase with increasing $\mathrm{CaSiO}_{3}$ concentration. The highest values were found in plants treated with $50 \mathrm{mM} \mathrm{NaCl}$ and $2 \mathrm{mM} \mathrm{CaSiO}_{3}$. The RWC increased by the application of $\mathrm{CaSiO}_{3}$. Application of $2 \mathrm{mM} \mathrm{CaSiO} 3$ to rice plants without $\mathrm{NaCl}$ treatment and $50 \mathrm{mM} \mathrm{NaCl}$ treatment showed significantly different changes in the RWC ( $p<0.05)$ compared to the control. Rice plants exposed to $\mathrm{NaCl}$ treatment showed lower RWC values. In line with Rahman et al. (2016), these results indicate an imbalance of water status in cells and the cell environment due to the excess $\mathrm{Na}^{+}$and $\mathrm{Cl}^{-}$ion accumulation, resulting in osmotic stress occurring in plants.

Proline levels. Proline levels of rice 'Inpari 35', which were treated with $50 \mathrm{mM} \mathrm{NaCl}$, decreased with $1 \mathrm{mM} \mathrm{CaSiO}$ but increased by $2 \mathrm{mM} \mathrm{CaSiO}_{3}$. The proline levels of rice 'Inpari $35^{\prime}$ with $37.5 \mathrm{mM}$ and $50 \mathrm{mM} \mathrm{NaCl}$ treatment increased along with the increase in the $\mathrm{CaSiO}_{3}$ concentration given (Table 8). It is known that the application of $2 \mathrm{mM} \mathrm{CaSiO}_{3}$ to $37.5 \mathrm{mM}$ and $50 \mathrm{mM}$ of $\mathrm{NaCl}$ showed a significant difference compared to the control. Control plants had the lowest proline levels compared to other treatment combinations. $\mathrm{CaSiO}_{3}$ can increase proline levels of rice plants treated with $\mathrm{NaCl}$ or without $\mathrm{NaCl}$.

Table 8 showed that $\mathrm{NaCl}$ treatment and $\mathrm{CaSiO}_{3}$ application significantly $(\mathrm{p} \leq 0.05)$ increased proline levels of rice 'Inpari 35' compared to the control. The proline accumulation in the rice 'Inpari 35' tended to increase in $\mathrm{NaCl}$ treatment with the application of $\mathrm{CaSiO}_{3}$. Calcium silicate plays a role in increasing proline in plants treated with $\mathrm{NaCl}$ and without $\mathrm{NaCl}$. The $2 \mathrm{mM} \mathrm{CaSiO}_{3}$ application increased proline levels in the rice 'Inpari 35' compared to control and plants with $\mathrm{NaCl}$ treatment without $\mathrm{CaSiO}_{3}$.

Table 8. Proline levels of rice 'Inpari 35 ' after treated with $\mathrm{CaSiO} 3$ and $\mathrm{NaCl}$ for 3 weeks.

\begin{tabular}{lllll}
\hline $\mathrm{NaCl}$ & \multicolumn{2}{l}{$\mathrm{CaSiO}_{3}(\mathrm{mM})$} & & \multirow{2}{*}{ Average } \\
$(\mathrm{mM})$ & 0 & 1 & 2 & \\
\hline 0 & $0.391 \mathrm{a}$ & $0.722 \mathrm{ab}$ & $0.619 \mathrm{ab}$ & $0.576 \mathrm{a}$ \\
37.5 & $0.785 \mathrm{~b}$ & $0.843 \mathrm{~b}$ & $0.993 \mathrm{~b}$ & $0.874 \mathrm{~b}$ \\
50 & $0.763 \mathrm{~b}$ & $0.664 \mathrm{ab}$ & $0.782 \mathrm{~b}$ & $0.736 \mathrm{ab}$ \\
Average & $0.646 \mathrm{a}$ & $0.743 \mathrm{a}$ & $0.798 \mathrm{a}$ & \\
\hline
\end{tabular}

Note: Numbers followed by the same letters in columns and rows show insignificant differences based on the DMRT test with a confidence level of $95 \%$.

When plants are exposed to abiotic stress, such as $\mathrm{NaCl}$, they store proline as a resistant strategy. Proline accumulation in cells has been shown to influence the osmotic equilibrium between the cell and cytosolic environments (Salsinha et al., 2020). Proline accumulation decreased significantly in the presence of $\mathrm{Si}$ in 
all stress treatments. However, the drop was only significant for plants exposed to severe salinity stress (El Moukhtari et al., 2020). As Zargar et al. (2019) explain, although plants are grown hydroponically, other researchers have demonstrated that when silicates are supplied to plants under low salinity stress, yields do not alter, regardless of whether the plants are cultivated in pots using sand, soil, or substrate. This suggests that $\mathrm{CaSiO}_{3}$ can be applied to plants in areas with high salinity.

\section{CONCLUSION}

$\mathrm{NaCl}$ treatment causes inhibit plant growth. The concentration of $50 \mathrm{mM} \mathrm{NaCl}$ reduced leaves number of rice 'Inpari 35'. Application of $2 \mathrm{mM} \mathrm{CaSiO}_{3}$ increased plant height and leaves number under $50 \mathrm{mM} \mathrm{NaCl}$ treatment. Chlorophyll level, carotenoid level, proline level, relative water content, and membrane stability index increased due to $\mathrm{NaCl}$ and calcium silicate treatment combination.

\section{ACKNOWLEDGEMENTS}

The authors are thankful for the facility support provided by the Faculty of Biology, Universitas Gadjah Mada. This research was supported through Lecturer and Student Collaboration Research Grant Faculty of Biology, Universitas Gadjah Mada, No. 987/UN1/FBI/KSA/PT.01.03/2021.

\section{REFERENCES}

Aini N, Sumiya WD, Syekhfani DR, Setiawan A. 2014. Kajian pertumbuhan, kandungan klorofil dan hasil beberapa genotipe tanaman kedelai (Glycine max L.) pada kondisi salinitas. Prosiding Seminar Nasional Lahan Sub Optimal. September 26-27, 2014. Palembang: Universitas Jambi. ISBN 979 587-529-9. pp 591-597.

Almeida DM, Oliveira MM, Saibo NJM. 2017. Regulation of $\mathrm{Na}^{+}$and $\mathrm{K}^{+}$homeostasis in plants: towards improved salt stress tolerance in crop plants. Genetics and Molecular Biology. vol 40: 326-345. doi: https://doi.org/10.1590/1678-4685GMB-2016-0106.

Amirjani MR. 2011. Effect of salinity stress on growth, sugar content, pigments and enzyme activity of rice. International Journal of Botany. vol 7(1): 73-81. doi: https://dx.doi.org/10.3923/ijb.2011.73.81.

Bates LS, Waldren RP, Teare ID. 1973. Rapid determination of free proline for water-stress studies. Plant and Soil. vol 39: 205-207. doi:
https://doi.org/10.1007/BF00018060.

Bhat JA, Shivaraj SM, Singh P, Navadagi DB, Tripathi DK, Dash PK, Solanke AU, Sonah H, Deshmukh R. 2019. Role of silicon in mitigation of heavy metal stresses in crop plants. Plants. vol 8(3): 1-20. doi: https://doi.org/10.3390/plants8030071.

Chen D, Wang S, Yin L, Deng X. 2018. How does silicon mediate plant water uptake and loss under water deficiency?. Frontiers in Plant Science. vol 9: 1-7. doi: https://doi.org/10.3389/fpls.2018.00281.

Chen W, Yao X, Cai K, Chen J. 2011. Silicon alleviates drought stress of rice plants by improving plant water status, photosynthesis and mineral nutrient absorption. Biological Trace Element Research. vol 142(1): 67-76. doi: https://doi.org/10.1007/s12011010-8742-x.

Cheng H, Inyang A, Li CD, Fei J, Zhou YW, Wang YS. 2020. Salt tolerance and exclusion in the mangrove plant Avicennia marina in relation to root apoplastic barriers. Ecotoxicology. vol 29(6): 676-683. doi: https://doi.org/10.1007/s10646-020-02203-6.

Chun SC, Paramasivan M, Chandrasekaran M. 2018. Proline accumulation influenced by osmotic stress in arbuscular mycorrhizal symbiotic plants. Frontiers in Microbiology. vol 9: 1-13. doi: https://doi.org/10.3389/fmicb.2018.02525.

Das P, Nutan KK, Singla-Pareek SL, Pareek A. 2015. Understanding salinity responses and adopting 'omics-based' approaches to generate salinity tolerant cultivars of rice. Frontiers in Plant Science. vol 6: 1-16. doi: https://doi.org/10.3389/fpls.2015.00712.

Dolatabadian A, Sanavy SAMM, Ghanati F. 2011. Effect of salinity on growth, xylem structure and anatomical characteristics of soybean. Notulae Scientia Biologicae. vol 3(1): 41-45. doi: http://dx.doi.org/10.15835/nsb315627.

El Moukhtari A, Cabassa-Hourton C, Farissi M, Savouré A. 2020. How does proline treatment promote salt stress tolerance during crop plant development? Frontiers in Plant Science. vol 11: 1-16. doi: https://doi.org/10.3389/fpls.2020.01127.

Fleck AT, Nye T, Repenning C, Stahl F, Zahn M, Schenk MK. 2011. Silicon enhances suberization and lignification in roots of rice (Oryza sativa). Journal of Experimental Botany. vol 62(6): 2001-2011. doi: https://doi.org/10.1093/jxb/erq392.

Gao HJ, Yang HY, Bai JP, Liang XY, Lou Y, Zhang JL, Wang D, Zhang JL, Niu SQ, Chen YL. 2015. Ultrastructural and physiological responses of potato (Solanum tuberosum L.) plantlets to gradient saline stress. Frontiers in Plant Science. vol 5: 114. doi: https://doi.org/10.3389/fpls.2014.00787.

Ghosh N, Adak MK, Ghosh PD, Gupta S, Sen Gupta DN, Mandal C. 2011. Differential responses of two rice varieties to salt stress. Plant Biotechnology Reports. vol 5(1): 89-103. doi: https://doi.org/10.1007/s11816-010-0163-y.

Gilliham M, Dayod M, Hocking BJ, Xu B, Conn SJ, Kaiser BN, Leigh RA, Tyerman SD. 2011. Calcium 
delivery and storage in plant leaves: exploring the link with water flow. Journal of Experimental Botany. vol 62(7): 2233-2250. doi: https://doi.org/10.1093/jxb/err111.

González L, González-Vilar M. 2001. Determination of relative water content. Handbook of Plant Ecophysiology Techniques. Dordrecht: Springer. pp 207-212. doi: https://doi.org/10.1007/0-30648057-3_14.

Harborne AJ. 1998. Phytochemical methods: A guide to modern techniques of plant analysis. $3 r^{d}$ Ed. New York: Springer. p 316.

Hassani A, Azapagic A, Shokri N. 2020. Predicting longterm dynamics of soil salinity and sodicity on a global scale. Proceedings of the National Academy of Sciences. vol 117(52): 33017-33027. doi: https://doi.org/10.1073/pnas.2013771117.

Hussain MI, Muscolo A, Farooq M, Ahmad W. 2019. Sustainable use and management of nonconventional water resources for rehabilitation of marginal lands in arid and semiarid environments. Agricultural Water Management. vol 221: 462 476.

doi: https://doi.org/10.1016/j.agwat.2019.04.014.

Ikhsanti A, Kurniasih B, Indradewa D. 2018. Pengaruh aplikasi silika terhadap pertumbuhan dan hasil tanaman padi (Oryza sativa L.) pada kondisi salin. Vegetalika. Vol 7(4): 1-11. doi: https://doi.org/10.22146/veg.41144.

Jayantie G, Yunus A, Pujiasmanto B, Widiyastuti Y. 2017. Pertumbuhan dan kandungan asam oleanolat rumput mutiara (Hedyotis Corymbosa) pada berbagai dosis pupuk kandang sapi dan pupuk organik cair. Agrotechnology Research Journal. vol 1(2): $13-18$. https://doi.org/10.20961/agrotechresj.v1i2.18880.

Jiang L, Deng X, Seto KC. The impact of urban expansion on agricultural land use intensity in China. Land Use Policy. vol 35: 33-39. doi: https://doi.org/10.1016/j.landusepol.2013.04.011.

Kafi M, Rahimi Z. 2011. Effect of salinity and silicon on root characteristics, growth, water status, proline content and ion accumulation of purslane (Portulaca oleracea L.). Soil Science and Plant Nutrition. $\quad$ vol 57(2): 341-347. doi: https://doi.org/10.1080/00380768.2011.567398.

Khare T, Kumar V, Kishor PK. 2015. $\mathrm{Na}^{+}$and $\mathrm{Cl}^{-}$ions show additive effects under $\mathrm{NaCl}$ stress on induction of oxidative stress and the responsive antioxidative defense in rice. Protoplasma. vol 252(4): 1149-1165. doi: https://doi.org/10.1007/s00709-014-0749-2.

Luyckx M, Hausman JF, Lutts S, Guerriero G. 2017. Silicon and plants: current knowledge and technological perspectives. Frontiers in Plant Science. $\quad$ vol 8: 1-8. doi: https://doi.org/10.3389/fpls.2017.00411.

Machado RM, Serralheiro RP. 2017. Soil salinity: effect on vegetable crop growth, management practices to prevent and mitigate soil salinization.
Horticulturae. vol 3(2): 1-13. doi: https://doi.org/10.3390/horticulturae3020030.

Mahbubi A. 2013. Model dinamis supply chain beras berkelanjutan dalam upaya ketahanan pangan nasional. Jurnal Manajemen \& Agribisnis. vol 10(2): 81-89. doi: https://doi.org/10.17358/jma.10.2.81-89.

Maoka T. 2020. Carotenoids as natural functional pigments. Journal of Natural Medicines. vol 74(1): 1-6. doi: https://doi.org/10.1007/s11418-01901364-x.

Meena VD, Dotaniya ML, Coumar V, Rajendiran S, Ajay A, Kundu S, Rao AS. 2014. A case for silicon fertilization to improve crop yields in tropical soils. Proceedings of the National Academy of Sciences, India Section B: Biological Sciences. vol 84(3): 505-518. doi: https://doi.org/10.1007/s40011-0130270-y.

Mulyani A, Nursyamsi D, Syakir M. 2017. Strategi Pemanfaatan sumberdaya lahan untuk pencapaian swasembada beras berkelanjutan. Jurnal Sumberdaya Lahan. vol 11(1): 11-22. doi: http://dx.doi.org/10.21082/jsdl.v11n1.2017.11-22.

Polash MA, Sakil MA, Tahjib-Ul-Arif M, Hossain MA. 2018. Effect of salinity on osmolytes and relative water content of selected rice genotypes. Tropical Plant Research. vol 5(2): 227-232. doi: https://doi.org/10.22271/tpr.2018.v5.i2.029.

Rachmawati D, Ramadhani AN, Fatikhasari Z. 2021. The effect of silicate fertilizer on the root development of rice and its tolerance to salinity stress. IOP Conference Series: Earth and Environmental Science. vol 724(1): 1-9. doi: https://doi.org/10.1088/1755-1315/724/1/012004.

Rad HE, Aref F, Rezaei M. 2012. Response of rice to different salinity levels during different growth stages. Research Journal of Applied Sciences, Engineering and Technology. vol 4(17): 3040 3047.

Rahman A, Nahar K, Hasanuzzaman M, Fujita M. 2016. Calcium supplementation improves $\mathrm{Na}+\mathrm{K}+$ ratio, antioxidant defense and glyoxalase systems in saltstressed rice seedlings. Frontiers in Plant Science. vol 7: 1-16. doi: https://doi.org/10.3389/fpls.2016.00609.

Reddy IN, Kim BK, Yoon IS, Kim KH, Kwon TR. Salt tolerance in rice: focus on mechanisms and approaches. Rice Science. vol 24(3): 123-144. doi: https://doi.org/10.1016/j.rsci.2016.09.004.

Rizwan M, Ali S, Ibrahim M, Farid M, Adrees M, Bharwana SA, Zia-ur-Rehman M, Qayyum MF, Abbas F. 2015. Mechanisms of silicon-mediated alleviation of drought and salt stress in plants: a review. Environmental Science and Pollution Research. vol 22(20): 15416-15431. doi: https://doi.org/10.1007/s11356-015-5305-x.

Salsinha YC, Maryani ID, Purwestri YA, Rachmawati D. 2021. Morphological and anatomical characteristics of Indonesian rice roots from East Nusa Tenggara contribute to drought tolerance. Asian Journal of 
Agriculture and Biology. vol 2021(1): 1-11. doi: https://doi.org/10.35495/ajab.2020.05.304.

Septanti KS, Saptana S. 2019. Potensi pemanfaatan kearifan lokal untuk menahan konversi lahan sawah ke nonsawah. Forum penelitian Agro Ekonomi. vol 37(1): 59-75. doi: http://dx.doi.org/10.21082/fae.v37n1.2019.59-75.

Savvas D, Ntatsi G. 2015. Biostimulant activity of silicon in horticulture. Scientia Horticulturae. vol 196: 6681.

doi: https://doi.org/10.1016/j.scienta.2015.09.010.

Senguttuvel P, Vijayalakshmi C, Thiyagarajan K, Sritharan R, Geetha S, KannanBapu JR, Viraktamath BC. 2013. Differential response of rice seedlings to salt stress in relation to antioxidant enzyme activity and membrane stability index. Archives of Agronomy and Soil Science. vol 59(10): 1359-1371. doi: https://doi.org/10.1080/03650340.2012.724170.

Shah SH, Houborg R, McCabe MF. 2017. Response of chlorophyll, carotenoid and SPAD-502

Taïbi K, Taïbi F, Abderrahim LA, Ennajah A, Belkhodja M, Mulet JM. 2016. Effect of salt stress on growth, chlorophyll content, lipid peroxidation and antioxidant defence systems in Phaseolus vulgaris L. South African Journal of Botany. vol 105: 306312.

doi: https://doi.org/10.1016/j.sajb.2016.03.011.

Teh CY, Mahmood M, Shaharuddin NA, Ho CL. 2015. In vitro rice shoot apices as simple model to study the effect of $\mathrm{NaCl}$ and the potential of exogenous proline and glutathione in mitigating salinity stress. Plant Growth Regulation. vol 75(3): 771-781. doi: https://doi.org/10.1007/s10725-014-9980-2.

Wani AB, Chadar H, Wani AH, Singh S, Upadhyay N. 2017. Salicylic acid to decrease plant stress. Environmental Chemistry Letters. vol 15(1): 101123. doi: https://doi.org/10.1007/s10311-016-05840.

Weisany W, Sohrabi Y, Heidari G, Siosemardeh A, Ghassemi-Golezani K. 2012. Changes in antioxidant enzymes activity and plant performance by salinity stress and zinc application in soybean (Glycine max L.). Plant Omics. vol 5(2): 60-67.

Yoshida S, Forno DA, Cock JH, Gomez KA. 1976. measurement to salinity and nutrient stress in wheat (Triticum aestivum L.). Agronomy. vol 7(3): 1-21. doi: https://doi.org/10.3390/agronomy7030061.

Suhartini T, Harjosudarmo TZP. 2017. Toleransi plasma nutfah padi lokal terhadap salinitas. Buletin Plasma Nutfah. $\quad$ vol 23(1): 51-58. doi: http://dx.doi.org/10.21082/blpn.v23n1.2017.p5158.

Sunartomo AF. 2015. Perkembangan konversi lahan pertanian di Kabupaten Jember. Agriekonomika. vol 4(1): 22-36. doi: https://doi.org/10.21107/agriekonomika.v4i1.671.

Swapna S, Shylaraj KS. 2017. Screening for osmotic stress responses in rice varieties under drought condition. Rice Science. vol 24(5): 253-263. doi: https://doi.org/10.1016/j.rsci.2017.04.004.

Swinton SM, Babcock BA, James LK, Bandaru V. 2011. Higher US crop prices trigger little area expansion so marginal land for biofuel crops is limited. Energy Policy. vol 39(9): 5254-5248. doi: https://doi.org/10.1016/j.enpol.2011.05.039. Laboratory manual for physiological studies of rice. $3^{\text {rd }}$ Ed. Los Baños: International Rice Research Institute. p 61 .

Zargar SM, Mahajan R, Bhat JA, Nazir M, Deshmukh R. 2019. Role of silicon in plant stress tolerance: opportunities to achieve a sustainable cropping system. 3 Biotech. vol 9(3): 1-16. doi: https://doi.org/10.1007/s13205-019-1613-z.

Zhang $\mathrm{H}, \mathrm{Hu} \mathrm{H}$, Zhang X, Wang K, Song T, Zeng F. 2012. Detecting Suaeda salsa L. chlorophyll fluorescence response to salinity stress by using hyperspectral reflectance. Acta Physiologiae Plantarum. vol 34(2): 581-588. doi: https://doi.org/10.1007/s11738-011-0857-y.

Zhao C, Zhang H, Song C, Zhu JK, Shabala S. 2020. Mechanisms of plant responses and adaptation to soil salinity. The Innovation. vol 1(1): 1-41. doi: https://doi.org/10.1016/j.xinn.2020.100017.

Zhou D, Lin Z, Liu L, Zimmermann D. 2013. Assessing secondary soil salinization risk based on the PSR sustainability framework. Journal of Environmental Management. vol 128: 642-654. doi: https://doi.org/10.1016/j.jenvman.2013.06.025. 